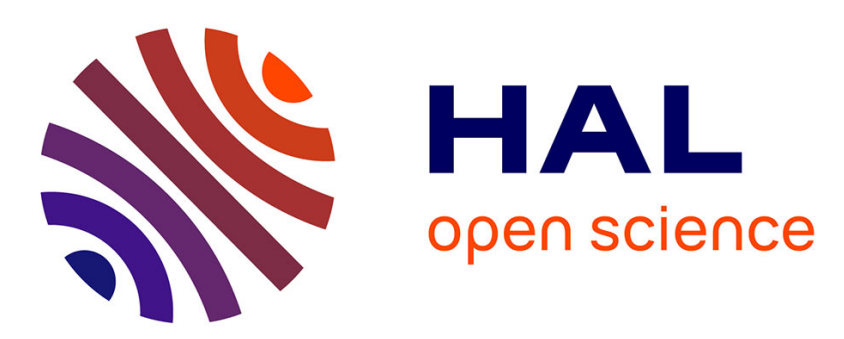

\title{
Changes in bird distribution in a Central European country between 1985-1989 and 2001-2003
}

Jaroslav Koleček, Jiří Reif, Karel Štastný, Vladimír Bejček

\section{To cite this version:}

Jaroslav Koleček, Jiří Reif, Karel Štastný, Vladimír Bejček. Changes in bird distribution in a Central European country between 1985-1989 and 2001-2003. Journal für Ornithologie = Journal of Ornithology, 2010, 151 (4), pp.923-932. 10.1007/s10336-010-0532-x . hal-00596615

\section{HAL Id: hal-00596615 https://hal.science/hal-00596615}

Submitted on 28 May 2011

HAL is a multi-disciplinary open access archive for the deposit and dissemination of scientific research documents, whether they are published or not. The documents may come from teaching and research institutions in France or abroad, or from public or private research centers.
L'archive ouverte pluridisciplinaire HAL, est destinée au dépôt et à la diffusion de documents scientifiques de niveau recherche, publiés ou non, émanant des établissements d'enseignement et de recherche français ou étrangers, des laboratoires publics ou privés. 


\section{Changes in bird distribution in a Central-European}

\section{2 country between $1985-1989$ and $2001-2003$}

\section{Jaroslav Koleček, Jiří Reif, Karel Št’astný, Vladimír Bejček}

Abstract European birds have been significantly affected by dramatic environmental changes during the last decades. The effects of these changes on species richness and distribution in particular countries remain poorly understood due to a lack of high-quality, large-scale data standardized over time. This is especially true in Central and Eastern Europe. On a model group of birds in the Czech Republic (countrywide atlas mapping data), we examined whether long-term changes of species richness and distribution between 1985-1989 and 2001-2003 differed among groups of species defined by their habitat requirements, type of distribution in Europe, migratory strategy, and the degree of national legal protection. Further, we investigated the effects of colonizers and local extinctions on these changes. Whereas the number of species in the whole country remained the same in both periods (208 species), species composition had changed. Increasing occupancy (i.e., number of occupied mapping squares) was observed in species of forest and wetland habitats, in short-distance migrants and in non-protected species. Southern species also positively changed their occupancy but this pattern disappeared after the inclusion of six species dependent on extensively cultivated farmland that went extinct between mappings. The overall occupancy of all species together

21 showed positive changes after excluding colonizers and extinct species. We suggest that the improvement of environmental conditions after 1990 caused the stability of or increased the distribution of common birds in the Czech Republic and it was the disappearance of specific

24 farmland practices that might cause the loss of several species. 
26 Keywords bird community, species richness, distribution, central Europe, global change,

$27 \quad$ land use

29 J. Koleček (corresponding author)

30 Department of Zoology and Laboratory of Ornithology, Faculty of Science, Palacký

31 University,

32 tř. Svobody 26, 77146 Olomouc, Czech Republic

33 e-mail: j.kolecek@email.cz

34

35

J. Reif

36 Institute for Environmental Studies, Faculty of Science, Charles University in Prague,

Benátská 2, 12801 Praha 2, Czech Republic

38

39 K. Št’astný and V. Bejček

40 Department of Ecology, Faculty of Environmental Sciences, Czech University of Life

41 Sciences,

42 Kamýcká 1176, 16521 Praha 6, Czech Republic

43

44 
Biodiversity conservation is one of the fundamental objectives of current initiatives for nature protection (Primack 2006). Although most attention is paid to the ongoing decline of global species richness (Swanson 1998), we should bear in mind that management measures are most frequently implemented at local or regional levels, usually within individual states (Lenzen et al. 2008; Yamamura 2008; Orłowski and Ławniczak 2009). Local change in species richness is determined by the number of species which colonize the area and the number of species that disappear. Local colonization and extinction rates are related to the sensitivity of particular species to current changes in the landscape (Donald et al. 2007; Lenzen et al. 2008). For effective conservation management it is, therefore, important to see whether species undergoing range retraction have different ecological traits from species with expanding ranges. For this purpose, we can examine the mean change in regional distribution of groups of species with defined ecological characteristics (Gregory et al. 2005, Jiguet et al. 2007, Van Turnhout et al. 2010).

Such an "ecological-group" approach has been used successfully for the examination

66 of temporal changes in regional breeding bird distribution in several Western European countries (Gregory et al. 2004, Julliard et al. 2004, Lemoine et al. 2007, Van Turnhout et al. 2007, Bauer et al. 2008). These studies have found prominent effects of various environmental changes on European birds such as the intensification of farming practices, urbanization and global climate change or habitat degradation on stop-over and wintering sites in the Mediterranean region and Sahel zone (Feranec et al. 2000; Jongman 2002, Opdam and Wascher 2004; Moreno-Rueda and Pizarro 2008; Schaefer et al. 2008).

Despite this large body of evidence, our information about factors affecting changes in bird distribution is incomplete due to an apparent regional bias in these studies. Findings from 
former communist Central and Eastern European countries are based only on a few local scale results (e.g., Tryjanowski 2000, Verhulst et al. 2004, Goławski 2006, Orłowski and Ławniczak 2009) and their generalisation is thus problematic. At the same time, factors affecting bird distribution might differ between Western and Eastern European countries: agriculture was less intensive in the East (Donald et al. 2001), implementation of conservation legislation was delayed (Donald et al. 2007) and many migratory species use different flyways and wintering grounds (Busse 2001, Cepák et al. 2008). The examination of whether the patterns found in Western parts of the European continent also hold true in former communist Central and Eastern European countries is thus of high conservation importance. In this respect, birds of the Czech Republic represent an ideal opportunity to fill this knowledge gap. Their breeding distribution was mapped using a standardized technique in two mapping sessions during the last decades: in 1985-1989 and 2001-2003. Moreover, their ecological requirements are well known and documented (Hudec 1983, 1994; Hudec and Št’astný 2005; Cepák et al. 2008) enabling the sorting of particular species into various ecological groups.

Based on the results of studies of European bird communities, we can formulate the following predictions about recent changes in distribution of particular ecological groups of Czech birds. First, landscape changes, such as the loss of extensively cultivated farmland due to agricultural intensification or land abandonment followed by forest spread, should reduce the distribution of farmland birds and increase the distribution of forest species (Lenzen et al. 2008; Reif et al. 2008a; Orłowski and Ławniczak 2009). Second, the increase in the average annual temperature should have a positive effect on the distribution of south-European species and a negative impact on the north-European ones (Bauer et al. 2008; Reif et al. 2008b). Third, global warming, along with the degradation of wintering habitats, should lead to an increase in the distribution of resident species and to a decrease of migrants (Schaefer et al. 
2008). Fourth, legal protection should have a positive impact on protected species compared

101 to unprotected ones (Donald et al. 2007).

The aim of the study was to examine these predictions comparing particular ecological groups of Czech birds between the two mapping periods. For each species group, we have

104 focused on changes in breeding distribution. We have paid special attention to the species that 105 colonized the country or went extinct between the mappings and how these species influenced 106 the observed patterns.

\section{Methods}

111 Bird distribution data

113 We used data from the two atlases of breeding bird distribution (hereafter Atlases) in the

114 Czech Republic covering the period 1985-1989 (Št’astný et al. 1996) and 2001-2003 (Št’astný 115 et al. 2006). Data was collected in a unified network of 628 squares of $10^{\prime}$ longitude and 6'

116 latitude (roughly 12 by $11.1 \mathrm{~km}$ ) evenly covering the entire territory of the country. The method of fieldwork was based on the contributions of a high number of volunteers (750 and

118532 in the first and second mapping periods, respectively) and was the same in both Atlases.

119 Each volunteer was requested to survey all habitats in a selected square. It was recommended

120 they start with the most frequent habitats (fields, meadows, forests, towns, villages, etc.) and 121 then move onto rarer ones (water bodies, wetlands, streams, etc.). Finally, a targeted search 122 was carried out for individual species in appropriate environments or at appropriate times 123 e.g., at dusk in case of the owls, crakes, nightingales etc. Field observations of each bird 124 species in the particular mapping squares were recorded using 17 numerical breeding codes 
125 with respect to the probability of its breeding occurence, according to the standards used in

126 Europe (Hagemeijer and Blair 1997).

The distribution of each species (hereafter occupancy) was expressed as the number of occupied squares with categories of "probable" or "confirmed breeding" (breeding codes 316 in Hagemeijer and Blair 1997) in respective mapping periods. There were 215 species

130 conforming to these criteria.

Definition of explanatory variables

We have recognized the following species groups (Appendix 1) differing in (i) habitat requirements, i.e., forest species (78 species in the first and 80 in the second mapping), wetland species (61 / 65), farmland species (50 / 44) and urban species (19 / 19), (ii) migration strategy, i.e., resident species (45 / 44), partial migrants (22 / 23), short-distance migrants (71 / 74) and long-distance migrants (70 / 67), (iii) breeding distribution in Europe,

140 i.e., northern species (68 / 69), southern species (53 / 51), central species (22 / 22) and

141 widespread species (65 / 66), and (iv) legal protection in the Czech Republic, i.e., critically 142 endangered (30 / 28), highly endangered (56 / 55), endangered (28 / 28) and species without 143 any special legal protection (94 / 97). The terms like "endangered" do not describe the real

144 level of threat but they are the title of the official categories of legal protection listed in Czech 145 conservation law (Anonymus 2008). Therefore, a "critically endangered" species is under the 146 highest conservation concern according to Czech conservation law but in reality it may not be 147 more threatened than other species. The real levels of threat to a particular bird species in the 148 Czech Republic are currently unknown as no one has performed any formal analysis (Voříšek 149 et al. 2008). 
Most of the species used for further analyses were already sorted into these categories

151 in Reif et al. (2006, 2008b) and Vorríšek et al. (2008). For the categorization of the remaining

152 species, we used the following literature sources: Hudec $(1983,1994)$ and Hudec and Št'astný

153 (2005) for the habitat requirements, Anonymus (2008) for legal protection status and

154 Hagemeijer and Blair (1997) for the breeding distribution in Europe.

Determination of particular groups defined by different breeding distributions in

156 Europe followed the two-step assessment procedure described in Reif et al. (2008b). First, we divided Europe into three large regions with respect to the location of the Czech Republic: the northern region had its southern boundary five geographical degrees north of the latitudinal midpoint of the Czech Republic, the southern region had its northern boundary five degrees

160 south of the midpoint of the Czech Republic and the central region laid between the northern 161 and southern regions. These regions broadly correspond to the biogeographical divisions of 162 Europe. The Mediterranean region is in the south, the boreal region is in the north and the continental region is in the central part (European Environmental Agency 2006). In the

164 second step, we measured the area of the breeding range of each species in each region and

165 calculated the proportion of a region covered by the range of the focal species. Based on these 166 proportions, we defined four species groups differing in the latitudinal distributions of their 167 breeding ranges in Europe. As nearly all species occurring in the Czech Republic have 168 relatively large European breeding ranges distributed in all three regions, we could not use 169 strict criteria such as "northern species are those confined solely to northern region". Instead, 170 we used a criteria focused on the avoidance of a region in which a species has the lowest

171 proportion of its range. We thus recognized: (i) northern species whose ranges cover $<30 \%$ of 172 the southern region (e.g., Turdus pilaris); (ii) southern species whose ranges cover $<30 \%$ of 173 the northern region (e.g., Luscinia megarhynchos); (iii) central species whose ranges cover < $17430 \%$ of southern and northern regions (e.g., Parus palustris); (iv) widespread species whose 
ranges cover more than $30 \%$ of the area of each region (e.g., Passer domesticus). Although such species sorting is arbitrary to some extent, and indeed $30 \%$ has no biological meaning, we trust that it mirrors the real latitudinal preferences of a particular species. Migratory strategy of each particular species were excerpted from the new Czech and Slovak bird migration atlas (Cepák et al. 2008) which is based on all known ringing recoveries of Czech birds up to 2002.

\section{Statistical analysis}

We calculated the change in occupancy $(C)$ of each particular species between the two mapping periods using the formula introduced by Lemoine et al. (2007):

$$
\mathrm{C}=\left(\mathrm{N}_{2}-\mathrm{N}_{1}\right) /\left(\left(\mathrm{N}_{2}+\mathrm{N}_{1}\right) / 2\right)
$$

$\mathrm{N}_{1,2}$ is the occupancy of a given species in the first and second mapping period, respectively.

Positive values of $\mathrm{C}$ indicate increasing occupancy, negative values decreasing occupancy and where $\mathrm{C}=0$ there is an indication of no change (Lemoine et al. 2007).

To test whether mean occupancy of particular species groups increased or declined, we performed the one-sample t-tests. Each test tested the null hypothesis that the mean change in occupancy of a given group is zero. Performance of 16 repeated tests using the same dataset would result in an elevated risk of a Type I error (Zar 1996). To account for this factor, we have applied the Bonferroni correction, adjusting the 0.05 level of significance $(\alpha)$ to 0.0031 .

To test whether mean changes in occupancy differ among the focal species groups, we 
have applied analysis of variance (ANOVA). First, we have performed one-way ANOVAs for 201 each factor (i.e., habitat, European distribution, migratory strategy and protection status) separately. Tukey's HSD post hoc test was used to compare means where significant differences were found with the ANOVA. Second, we have examined the effects of each factor, controlling the influence of the others, using main-effects ANOVA.

Finally, we were interested in the influence of colonization/extinction processes on changes in the distribution of birds in the Czech Republic. For this purpose, we have excluded all species $(n=14)$ present only in one of the mapping periods and then repeated all the tests described above. Comparison of the outcome of the tests with and without such species revealed their possible influence.

\section{Results}

214 The number of species in the Czech Republic remained the same in both periods -208

215 species. Seven species went extinct in the Czech Republic during the time between the 216 mappings (Falco vespertinus, Otis tarda, Burhinus oedicnemus, Charadrius hiaticula,

217 Coracias garrulus, Lanius minor and L. senator) and, at the same time, seven species

218 colonized the country (Egretta alba, Anas penelope, Tadorna tadorna, Pandion haliaetus, 219 Aquila heliaca, Chlidonias hybridus and Otus scops). The prevailing characteristics of the 220 species which were not registered in the second mapping period were: farmland habitat (six 221 species), long-distance migratory strategy (six species), southern distribution (five species) and critically endangered protection status (four species). The colonizers were characterized by wetland habitat (five species), long-distance (three species) or short-distance migratory

224 strategy (three species), southern distribution (three species) and no legal protection (four 
species).

The overall mean change in occupancy between both mappings was not significantly different from zero (Table 1a). Regarding particular species groups, we found a positive change in occupancy in forest and wetland species, short-distance migrants and non-protected species. After application of the Bonferroni correction, the result remained significant in the wetland species only (Table 1a). No group showed a significantly negative change in mean occupancy, although the result in farmland birds approached the 0.05 significance level (Table 1a).

We applied analysis of variance to test whether some ecological characteristics would predict differences among the species groups in their mean changes in occupancy. We have found that habitat requirements were the only significant predictor of these changes, as shown by both one-way and main effects ANOVAs (Table 2a, b, Fig. 1). Post hoc comparisons using Tukey's HSD tests showed that both forest $(P=0.0138)$ and wetland $(P=0.0001)$ species extended their distribution more than farmland species.

After exclusion of the 14 species present only in one of the two mappings, we found 240 that the overall mean change in occupancy between the mappings was positive (Table 1b). 241 Further, the results showed increasing occupancy in southern species (Table 1b). Excluding colonizers and extinct species did not qualitatively change the results for forest, wetland and non-protected species (Table 1b). In contrast, change in short-distance migrants was no longer significant (Table 1b). After the Bonferroni correction, the overall average change in occupancy and change in southern and non-protected species remained significant (Table 1b). Exclusion of the 14 species, present only in one of both mappings, did not reveal any significant results in both one-way and main effects ANOVAs (Table 2c, d). 
252 Our results based on the analysis of the large-scale mapping data showed four striking patterns of changes in breeding bird distribution in the Czech Republic between 1985-1989 and 2001-2003: (i) dominant effect of habitat over all other factors, (ii) weaker but significant effects of European distribution, migratory strategy and protection status in some tests, (iii) influence of rare species on most of the observed patterns, (iv) prevalence of positive changes in bird distribution over the negative ones. The effects of habitat and European distribution were in congruence with our initial predictions, but the legal protection status showed the opposite pattern to what we had expected. The effect of migratory strategy did not support our prediction of decline in long-distance migrants and increase of residents.

The effect of habitat was caused by expansion of forest and wetland species in contrast to farmland birds. Since this contrast was not significant after excluding species detected in one mapping only, the marked difference between these habitat-defined species groups is probably caused by the extinction of six farmland species between the mapping periods: Falco vespertinus, Otis tarda, Burhinus oedicnemus, Coracias garrulus, Lanius minor and $L$. senator. Their disappearance from the Czech Republic indicates a possible adverse impact of the recent land use practices on these species. This result is somewhat surprising as the decrease in agricultural intensity after the fall of communism probably reduced the rate of population decline of common farmland birds in the Czech Republic (Reif et al. 2008a), 270 Poland (Goławski 2006) and Hungary (Verhulst et al. 2004). This land use change obviously 271 did not prevent more sensitive farmland species from extinction. The exact causes of the loss of these species remains unexplored. We can only speculate about the switch from an extensively cultivated agricultural landscape providing a heterogenous mosaic of habitats to

274 either highly intensive agriculture or the complete abandonment of arable land in the key 
areas for populations of these species (Konvička et al. 2006, 2008, Ludwig et al. 2009; see also Št’astný et al. 1996). The disappearance of these highly specialized species is consistent with Kerbiriou's et al. (2009) findings on the spread of tolerant species with a broad ecological niche leading to biotic homogenization of bird communities in France (Devictor et al. 2008) and the Netherlands (Van Turnhout et al. 2007).

The increasing occupancy of forest and wetland birds was found even if the species detected in only one mapping were excluded (although with lower significance). Therefore, we suggest that these patterns were caused mainly by extending distribution of common species already breeding in the Czech Republic and the colonization of the country by new species has only strenghtened this effect. In the case of forest birds, this result is in accordance with studies based on annual monitoring of populations of common species in the Czech Republic (Reif et al. 2007) and other parts of Europe (Gregory et al. 2007, Van Turnhout et al. 2007). It might be attributed to forest expansion, the alteration of forest age class composition towards older classes and/or by the impact of forest recovery after the reduction of imissions in the 1990s (Reif et al. 2007, 2008c). The increase of wetland birds was also confirmed in local bird communities in central and western Europe (Lemoine et al. 2007, Van Turnhout et al. 2010, Orłowski and Lawniczak 2009) and was probably caused by lower hunting pressure and the fact that many newly established nature reserves in the country protected wetland habitats (Málková \& Lacina 2002).

Southern species that bred in the Czech Republic in both mapping periods extended their occupancy, corresponding with findings of an earlier study focused on annual changes in abundance of common birds in the Czech Republic (Reif et al. 2008b). This result is consistent with the observations of climate change impact on bird species (Julliard et al. 2004, Jiguet et al. 2007, Bauer et al. 2008). It also corroborates predictions of future breeding bird distribution patterns modelled under various scenarios of climatic warming (Huntley et al. 
2007). Increasing occupancy of southern species, however, vanished after the inclusion of the

301 species which became extinct between the mappings. A more detailed focus on particular species uncovered the fact that decrease was caused by the extinction of the farmland species which were probably more affected by unfavourable land use practices than by the climate. This result implies that global warming itself is not a sufficient impetus for range expansion of the southern species, if their habitat is destroyed.

Regarding changes of distribution of birds with different migratory strategies, we have found two unexpected results: increased occupancy in short-distance migrants and no change in occupancy in long-distance migrants. The first pattern was driven by the expansion of several colonizers of wetland birds (Egretta alba, Anas penelope and Tadorna tadorna) and it was probably caused by habitat effects. The second pattern contrasts with observations of 311 population decline of long-distance migrants in several western European countries (e.g., Lemoine et al. 2007, Heldbjerg and Fox 2008) and might be attributable to the use of different migratory routes and/or wintering sites by the Czech populations (Busse 2001, Cepák et al. 314 2008). Increasing occupancy was found in non-protected species and the same result was

316 found in all species grouped together after the exclusion of species detected in one mapping only. These results imply that common birds probably benefited from changes in the Czech

318 landscape after 1990. In fact, components of the environment, including water, air, forests and 319 farmland were heavily affected by human activity within all of Europe in the late 1980s 320 (Moldan 1990). During the 1990s, the water quality and air pollution greatly improved and 321 there was also a sharp decrease in agricultural intensity. These positive changes were also 322 documented in Poland (Goławski 2006) and Hungary (Verhulst et al. 2004). Moreover, 323 forests, defoliated in extensive areas due to air pollution, started to recover (Anonymus 1996; 324 Reif et al. 2007, 2008a). At the same time, we have failed to find any significant positive 
effect of legal protection on the occupancy of species. The reason may lie in the low

326 effectiveness of direct conservation actions (Kumstátová et al. 2005). Czech nature conservation is probably not able to take care of problematic bird species (Voříšek et al. 2008). Further studies are needed to ensure that existing protected areas create suitable conditions for endangered birds' existence (e.g., Kollar and Wurm 1996).

To our knowledge, our study is the first attempt to examine the patterns of changes in breeding bird distribution on a country-wide level within the former Eastern block. Compared to the previous studies based on population trends from annual monitoring schemes (e.g.,

333 Gregory et al. 2007, Reif et al. 2008a, b, c), our breeding distribution mapping data involve

334 information about uncommon species (Van Turnhout et al. 2007). They are, therefore, less

335 biased and the observed patterns are more general. Our results imply that the major drivers of 336 changes (agricultural intensification, forest expansion, global climate change, biotic homogenization) are probably similar across European regions, although local specificities of

338 several aspects emerged (e.g., poor performance of legal protection). Future studies should 339 focus in more detail on the investigation of particular drivers.

Zusammnefassung

Veränderungen in der Vogelverbreitung in einem mitteleuropäischen Land zwischen

346 Europäische Vögel sind in den letzten Jahrzehnten signifikant von dramatischen

347 Umweltveränderungen betroffen worden. Die Effekte dieser Veränderungen auf den

348 Artenreichtum und die Verbreitung in bestimmten Ländern sind nach wie vor schlecht

349 verstanden, da hochwertige, großräumige Daten fehlen, die über die Zeit standardisiert sind. 
Dies trifft besonders auf Mittel- und Osteuropa zu. Anhand einer Modellgruppe von Vögeln

351 in Tschechien (landesweite Atlaskartierungsdaten) haben wir untersucht, ob sich

352 Langzeitveränderungen in Artenreichtum und Verbreitung zwischen 1985-1989 und 2001-

3532003 zwischen Artengruppen unterschieden, die anhand ihrer Habitatansprüche, ihrem

354 Verbreitungstyp in Europa, ihrer Zugstrategie und ihrem nationalen Schutzstatus voneinander

355 abgegrenzt sind. Außerdem haben wir die Effekte von Erstbesiedlungen und lokalen

356 Ausrottungen auf diese Veränderungen untersucht. Während die Artenzahl im gesamten Land

357 in beiden Zeiträumen gleich blieb (208 Arten), hat sich die Artenzusammensetzung verändert.

358 Zunehmende Besiedlung (d.h. Zahl besetzter Kartenquadrate) wurde für in Wald- und

359 Feuchtlandhabitaten vorkommende Arten, Kurzstreckenzieher und nicht geschützte Arten

360 beobachtet. Im Süden vorkommende Arten veränderten ihre Besiedlung ebenfalls zum

361 Positiven, doch dieses Muster verschwand nach der Einbeziehung von sechs Arten, die auf

362 extensiv bewirtschaftetes Ackerland angewiesen sind und zwischen den Kartierungen

363 ausstarben. Die gesamte Besiedlung aller Arten zusammengenommen zeigte positive

364 Veränderungen, nachdem Erstbesiedler und ausgestorbene Arten ausgeschlossen worden

365 waren. Wir schlagen vor, dass die Verbesserung der Umweltbedingungen nach 1990 die

366 Verbreitung von häufigen Vögeln in Tschechien stabilisierte oder ansteigen ließ, und der

367 Verlust mehrerer Arten könnte durch das Verschwinden spezifischer Ackerbautechniken

368 verursacht worden sein.

370 Acknowledgements Special thanks belongs to all the volunteers who participated in the 371 collection of data needed to write this paper. We thank Karel Weidinger, Martin Paclík and 372 two anonymous referees for their critical comments on the manuscript. Pamela and Kenneth 373 C. Lewis improved the English. The study was supported by the Grant Agency of the 374 Academy of Sciences of the Czech Republic (KJB601110919) and Ministry of Education of 
375 the Czech Republic (MSM 6198959212). The authors declare that they have no conflict of 376 interest.

\section{References}

Anonymus (1996) Environmental Yearbook of the Czech Republic 1995. Ministry of the

Anonymus (2008) Decree of the Ministry of the Environment of 11 Jun 1992, implementing selected provisions of Czech National Council Act No. 114/1992 Coll. on the protection of the environment and the natural landscape, in the wording till 4 Nov 2008

Bauer H-G, Lemoine N, Peintinger M (2008) Avian species richness and abundance at Lake

Busse P (2001) European passerine migration system - what is known and what is lacking.

Cepák J, Klvaňa P, Škopek J, Schröpfer L, Jelínek M, Hořák D, Formánek J, Zárybnický J

396 (2008) Czech and Slovak Bird Migration Atlas. Aventinum, Prague (in Czech with English summary) 
400 homogenization of bird communities in disturbed landscapes. Global Ecol Biogeogr 17:252-

$401 \quad 261$

402

403 Donald PF, Green RE, Heath MF (2001) Agricultural intensification and the collapse of

404 Europe's farmland bird populations. Proc R Soc Lond Ser B Biol Sci. 268:25-29

405

406 Donald PF, Sanderson FJ, Burfield IJ, Bierman SM, Gregory RD, Waliczky Z (2007)

407 International Conservation Policy Delivers Benefits for Birds in Europe. Science 317:810-

$408 \quad 813$

409

410 European Environmental Agency (2006) Biogeographical regions, Europe 2005. European

411 Environmental Agency, Copenhagen

412

413 Feranec J, Šúri M, Ot’ahel’ J, Cebecauer T, Kolář J, Soukup T, Zdeňková D, Waszmuth J,

414 Vájdea V, Víjdea A-M, Nitica C (2000) Inventory of major landscape changes in the Czech

415 Republic, Hungary, Romania and Slovak Republic 1970s-1990s. Int J Appl Earth Obs Geoinf

$416 \quad 2: 129-139$

417

418 Gregory RD, Noble DG, Custance J (2004) The state of play of farmland birds: population

419 trends and conservation status of lowland farmland birds in the United Kingdom. Ibis 146:1-

$420 \quad 13$

421

422 Gregory RD, van Strien A, Vorisek P, Meyling AWG, Noble DG, Foppen RPB, Gibbons DW

423 (2005) Developing indicators for European birds. Philos Trans R Soc B Biol Sci 360:269-288

424 
Gregory RD, Voř́̌šsek P, van Strien A, Meyling AWG, Jiguet F, Fornasari L, Reif J, Burfield

IJ (2007) Population trends of widespread woodland birds in Europe. Ibis 149:78-97

427

428

Goławski A (2006) Changes in numbers of some bird species in the agricultural landscape of eastern Poland. Ring 28:127-133

430

Hagemeijer WJM, Blair MJ (1997) The EBCC atlas of European breeding birds. Their

Heldbjerg H, Fox TAD (2008) Long-term population declines in Danish trans-Saharan migrant birds. Bird Study 55:267-279

436

Hudec K (1983) Fauna of Czechoslovakia: Birds III. Academia, Prague (in Czech with

German summary)

439

Hudec K (1994) Fauna of the Czech and Slovak Republic: Birds I. Academia, Prague (in

441 Czech with German summary)

442

443 Hudec K, Št’astný K (2005) Fauna of the Czech Republic: Birds II. Academia, Prague (in 444 Czech with German summary)

446 Huntley B, Green RE, Collingham YC, Willis SG (2007) A Climatic Atlas of European 447 Breeding Birds. Lynx Edicions, Barcelona

448

449 Jiguet F, Gadot AS, Julliard R, Newson SE, Couvet D (2007) Climate envelope life history 
traits and the resilience of birds facing global change. Global Change Biol 13:1672-1684

451

Jongman RHG (2002) Homogenisation and fragmentation of the European landscape:

Julliard R, Jiguet F, Couvet D (2004) Common birds facing global changes: what makes a species at risk? Glob Change Biol 10:148-154

Kerbiriou C, Le Viol I, Jiguet F, Devictor V (2009) More species, fewer specialists: 100 years of changes in community composition in an island biogeographical study. Divers Distrib 15:641-648

461

Kollar HP, Wurm H (1996) Zur Bestandssituation der Großtrappe (Otis t. tarda L., 1758) in Österreich. Natschutz Landschpflege Brandenbg Heft 1/2, 1996:7-9 (in German with English summary)

Konvička M, Fric Z, Beneš J (2006) Butterfly extinctions in European states: Do socioeconomic conditions matter more than physical geography? Glob Ecol Biogeogr 15:8292

Konvička M, Beneš J, Čížek O, Kopeček F, Konvička O, Vitaz L (2008) How too much care

kills species: Grassland reserves, agri-environmental schemes and extinction of Colias

474 Kumstátová T, Nová P, Marhoul P (2005) Assessment of conservation projects on animals 
475 endangered in the Czech Republic. AOPK ČR, Prague (in Czech)

476

477 Lemoine N, Bauer H-G, Peintinger M, Böhning-Gaese K (2007) Effects of Climate and Land478 Use Change on Species Abundance in a Central European Bird Community. Conserv Biol $479 \quad 21: 495-503$

480

481 Lenzen M, Lane A, Widmer-Cooper A, Williams M (2008) Effects of Land Use on

482 Threatened Species. Conserv Biol 23:294-306

483

484 Ludwig T, Storch I, Gärtner S (2009) Large-scale land use change may explain bird species

485 declines in semi-natural areas: the case of Black Grouse population collapse in Lower

486 Saxony, Germany. J Ornithol 150:871-882

487

488

Málková P, Lacina D (2002) Important Bird Areas in the Czech Republic. Czech Society for 489 Ornithology, Prague (in English and Czech)

490

491 Moldan B (1990) Environment of the Czech Republic. Development and statement until the 492 end of 1989. Academia, Prague (in Czech)

493

494 Moreno-Rueda G, Pizarro M (2008) Temperature differentially mediates species richness of 495 birds of different biogeographic types. Ardea 96:115-120

496

497 Opdam P, Wascher D (2004) Climate change meets habitat fragmentation: linking landscape 498 and biogeographical scale levels in research and conservation. Biol Conserv 117:285-297 499 
500 Orłowski G, Ławniczak D (2009) Changes in breeding bird populations in farmland of south-

501 western Poland between 1977-1979 and 2001. Folia Zool 58:228-239

502

503 Primack RB (2006) Essentials of Conservation Biology. Sinauer Associates, Andover

504

505 Reif J, Voř́íšek P, Št’astný K, Bejček V (2006) Population trends of birds in the Czech

506 Republic during 1982-2005. Sylvia 42:22-37

507

508 Reif J, Voříšek P, Št’astný K, Bejček V, Petr J (2007) Population increase of forest birds in the

509 Czech Republic between 1982 and 2003. Bird Study 54:248-255

510

511 Reif J, Voříšek P, Št’astný K, Bejček V, Petr J (2008a) Agricultural intensification and

512 farmland birds: new insights from a central European country. Ibis 150:596-605

513

514 Reif J, Voříšek P, Št’astný K, Koschová M, Bejček V (2008b) The impact of climate change

515 on long-term population trends of birds in a central European country. Anim Conserv 11:412-

$516 \quad 421$

517

518 Reif J, Storch D, Voříšek P, Št’astný K, Bejček V (2008c) Bird-habitat associations predict

519 population trends in central European forest and farmland birds. Biodivers Conserv 17:3307-

$520 \quad 3319$

521

522 Schaefer H-C, Jetz W, Böhning-Gaese K (2008) Impact of climate change on migratory birds:

523 community reassembly versus adaptation. Global Ecol Biogeogr 17:38-49

524 
525 Swanson TM (1998) The Economics and Ecology of Biodiversity Decline: The Forces

526 Driving Global change. Cambridge University Press, Cambridge

528 Št’astný K, Bejček V, Hudec K (1996) Atlas of Breeding Bird Distribution in the Czech

529 Republic. H \& H, Prague (in Czech with English summary)

530

531 Št’astný K, Bejček V, Hudec K (2006) Atlas of Breeding Bird Distribution in the Czech 532 Republic. Academia, Prague (in Czech with English summary)

534 Tryjanowski P (2000) Changes in breeding bird populations of some farmland birds in W

535 Poland in relation to changes in crop structure, weather conditions and number of predators.

536 Folia Zool 49:305-315

537

538 Van Turnhout CAM, Foppen RPB, Leuven RSEW, Siepel H, Esselink H (2007) Scale-

539 dependent homogenization: Changes in breeding bird diversity in the Netherlands over a 25-

540 year period. Biol Conserv 134:505-516

541

542 Van Turnhout CAM, Foppen RPB, Leuven RSEW, Van Strien A, Siepel H (2010) Life-

543 history and ecological correlates of population change in Dutch breeding birds. Biol Conserv

$544 \quad 143: 173-181$

545

546 Verhulst J, Báldi A, Kleijn D (2004) Relationship between land-use intensity and species

547 richness and abundance of birds in Hungary. Agric Ecosyst Environ 104:465-473

548

549 Voříšek P, Reif J, Št’astný K, Bejček V (2008) How effective can be the national law in 
550 protecting birds? A case study from the Czech Republic. Folia Zool 57:221-230

551

552 Yamamura Y, Amano T, Koizumi T, Mitsuda Y, Taki H, Okabe K (2008) Does land-use

553 change affect biodiversity dynamics at a macroecological scale? A case study of birds over

554 the past 20 years in Japan. Anim Conserv 12:110-119

555

556 Zar JH (1996) Biostatistical analysis. Prentice Hall, New Jersey

557

558

559

560

561

562

563

564

565

566

567

568

569

570

571

572

573

574

575

576

577 
Table 1 Changes in species richness (total number of species in the country) and occupancy (number of occupied mapping squares) of birds in the Czech Republic between 1985-1989 and 2001-2003 as revealed by the country-wide breeding distribution altas mapping. Species were sorted into groups defined by their habitat requirements, migratory strategy, European distribution and legal protection status in the Czech Republic. Statistics refer to single sample t-tests that tested the significance of change in occupancy of each group between the mapping periods. Significant differences $(P<0.05)$ are in bold type and those significant after the Bonferroni correction $(P<0.0031)$ are underlined. Tests were performed with (a) and without (b) 14 species that colonized the country or went extinct between the mapping periods. See Methods section for a detailed description of the calculation of change in occupancy and for more details on the sorting of species into the ecological groups

\begin{tabular}{|c|c|c|c|c|c|c|c|c|c|c|}
\hline & $\begin{array}{l}\text { Species } \\
\text { 1985-9 }\end{array}$ & $2001-3$ & $\begin{array}{l}\text { a) } \\
\text { Change in } \\
\text { occupancy } \\
( \pm \text { SE })\end{array}$ & $N$ & $t$ & $P$ & $\begin{array}{l}\text { b) } \\
\text { Change in } \\
\text { occupancy } \\
( \pm \text { SE })\end{array}$ & $N$ & $t$ & $P$ \\
\hline \multicolumn{11}{|l|}{ Habitat requirements } \\
\hline Farmland & 50 & 44 & $-0.21( \pm 0.11)$ & 50 & -1.92 & 0.0614 & $0.04( \pm 0.06)$ & 44 & 0.58 & 0.5626 \\
\hline Forest & 78 & 80 & $0.14( \pm 0.05)$ & 80 & 2.74 & 0.0076 & $0.09( \pm 0.04)$ & 78 & 2.33 & $\mathbf{0 . 0 2 2 0}$ \\
\hline Urban & 19 & 19 & $-0.09( \pm 0.06)$ & 19 & -1.42 & 0.1742 & $-0.09( \pm 0.06)$ & 19 & -1.41 & 0.1742 \\
\hline Wetland & 61 & 65 & $\underline{0.28( \pm 0.96)}$ & 66 & $\underline{3.10}$ & $\underline{0.0029}$ & $0.19( \pm 0.07)$ & 60 & 2.63 & 0.0107 \\
\hline \multicolumn{11}{|l|}{ Migratory strategy } \\
\hline Resident & 45 & 44 & $0.02( \pm 0.08)$ & 45 & 0.24 & 0.8127 & $0.06( \pm 0.06)$ & 44 & 1.03 & 0.3096 \\
\hline Partial migrants & 22 & 23 & $0.14( \pm 0.10)$ & 23 & 1.34 & 0.1934 & $0.05( \pm 0.06)$ & 22 & 0.87 & 0.3934 \\
\hline Short-distance migrants & 71 & 74 & $0.19( \pm 0.07)$ & 74 & 2.64 & 0.0102 & $0.11( \pm 0.06)$ & 71 & 1.90 & 0.0619 \\
\hline Long-distance migrants & 70 & 67 & $0.01( \pm 0.10)$ & 73 & 0.08 & 0.9328 & $0.10( \pm 0.05)$ & 64 & 1.94 & 0.0571 \\
\hline \multicolumn{11}{|l|}{ European distribution } \\
\hline Central & 22 & 22 & $0.02( \pm 0.17)$ & 23 & 0.09 & 0.9271 & $0.02( \pm 0.13)$ & 21 & 0.13 & 0.8947 \\
\hline Northern & 68 & 69 & $0.13( \pm 0.08)$ & 70 & 1.70 & 0.0930 & $0.11( \pm 0.06)$ & 67 & 1.70 & 0.0882 \\
\hline Southern & 53 & 51 & $0.10( \pm 0.12)$ & 56 & 0.86 & 0.3951 & $\underline{0.20( \pm 0.06)}$ & 48 & $\underline{3.14}$ & $\underline{0.0029}$ \\
\hline Widespread & 65 & 66 & $0.05( \pm 0.04)$ & 66 & 1.23 & 0.2239 & $0.02( \pm 0.03)$ & 65 & 0.73 & $\overline{0.4708}$ \\
\hline \multicolumn{11}{|l|}{ Protection status } \\
\hline Non-protected & 94 & 97 & $0.12( \pm 0.05)$ & 98 & 2.43 & 0.0168 & $\underline{0.06( \pm 0.02)}$ & 93 & 3.29 & $\underline{0.0014}$ \\
\hline Endangered & 28 & 28 & $0.03( \pm 0.06)$ & 28 & 0.43 & 0.6692 & $\overline{0.03( \pm 0.06)}$ & 28 & $\overline{0.43}$ & $\overline{0.6692}$ \\
\hline Highly endangered & 56 & 55 & $0.10( \pm 0.09)$ & 57 & 1.02 & 0.3137 & $0.14( \pm 0.07)$ & 54 & 1.86 & 0.0679 \\
\hline Critically endangered & 30 & 28 & $0.03( \pm 0.20)$ & 32 & 0.16 & 0.8769 & $0.19( \pm 0.16)$ & 26 & 1.21 & 0.2344 \\
\hline Total & 208 & 208 & $0.09( \pm 0.05)$ & 215 & 1.91 & 0.0576 & $\underline{0.09( \pm 0.03)}$ & 201 & $\underline{3.00}$ & $\underline{0.0030}$ \\
\hline
\end{tabular}


611

612

613

614

615

616

617

618

619

620

621

622

623

624

625

626

627

628

629

630

631

632

633

634

635

636

637

638

639

640

641

642

643

644

645

646

647

648

649

650

651

652

653

654

655

656

657

658

659

660

661

662

663

664

665

666

667

668

669

670

Table 2 The effects of ecological characteristics of bird species expressed as four factors on changes in their mean occupancy between 1985-1989 and 2001-2003 tested by one-way ANOVAs (seperate tests for each factor) with (a) and without (c) 14 species present in only one of the mappings, and by main effects ANOVAs (all factors included into one model) with (b) and without (d) 14 species present in only one of the mappings. See Table 1 for identification of the levels of each factor

\begin{tabular}{lllllllll}
\hline Factor & a ) & \multicolumn{3}{l}{ b) } & \multicolumn{3}{c}{ c) } & \multicolumn{3}{l}{ d) } \\
& $F_{3,211}$ & $P$ & $F_{3,202}$ & $P$ & $F_{3,197}$ & $P$ & $F_{3,188}$ & $P$ \\
\hline Habitat requirements & $\mathbf{6 . 6 0 4 0}$ & $\mathbf{0 . 0 0 0 3}$ & $\mathbf{5 . 7 6 9 1}$ & $\mathbf{0 . 0 0 0 8}$ & 2.4741 & 0.0628 & 2.1731 & 0.0926 \\
Migratory strategy & 1.1359 & 0.3355 & 0.2256 & 0.8785 & 1.1795 & 0.9102 & 0.1149 & 0.9512 \\
European distribution & 0.2533 & 0.8589 & 0.3632 & 0.7796 & 1.8702 & 0.1471 & 1.6522 & 0.1789 \\
Protection status & 0.2152 & 0.8858 & 0.3402 & 0.7963 & 1.0695 & 0.3631 & 0.2533 & 0.8589 \\
\hline
\end{tabular}


671

672

673

674

675

676

677

678

679

680

681

682

683

684

685

686

687

688

689

690

691

692

693

694

695

696

697

698

699

700

701

702

703

704

705

706

707

708

709

710

711

712

713

714

715

716

717

718

719

720

721

722

723

724

725

726

727

728

729

730

Fig. 1 Mean changes in the occupancy of Czech birds between 1985-1989 and 2001-2003 according to their habitat requirements. The vertical bars denote 0.95 confidence intervals. In one-way ANOVA, $\mathrm{F}_{3,211}=6.6040$ and $P=0.0003$. Pairwise comparisons of means by the Tukey test gave the following results: Forest different from Farmland $(P=0.0138)$ and Wetland different from Farmland $(P=0.0001)$ 
wetland), migratory strategy (migration: $\mathrm{R}$ - resident, $\mathrm{P}$ - partial migrants, $\mathrm{S}$ - short-distance migrants, $\mathrm{L}$ - longdistance migrants), European distribution (distribution: $\mathrm{C}$ - central, $\mathrm{N}$ - northern, $\mathrm{S}$ - southern, $\mathrm{W}$ - widespread) and legal protection status (protection: $\mathrm{N}$ - non-protected, $\mathrm{E}$ - endangered, $\mathrm{H}$ - highly endangered, $\mathrm{C}$ - critically endangered) in the Czech Republic

\begin{tabular}{|c|c|c|c|}
\hline Habitat & Migration & Distribution & Protection \\
\hline $\mathrm{F}$ & $\mathrm{R}$ & $\mathrm{W}$ & $\mathrm{E}$ \\
\hline $\mathrm{F}$ & $P$ & W & $\mathrm{H}$ \\
\hline W & $\mathrm{L}$ & $\mathrm{S}$ & $\mathrm{H}$ \\
\hline A & $\mathrm{L}$ & $\mathrm{N}$ & $\mathrm{N}$ \\
\hline W & $\mathrm{L}$ & $\mathrm{W}$ & $\mathrm{N}$ \\
\hline W & $\mathrm{L}$ & $\mathrm{N}$ & $\mathrm{N}$ \\
\hline W & $\mathrm{L}$ & $\mathrm{W}$ & $\mathrm{H}$ \\
\hline $\mathrm{F}$ & $\mathrm{R}$ & $\mathrm{W}$ & $\mathrm{N}$ \\
\hline $\mathrm{F}$ & $\mathrm{R}$ & $\mathrm{N}$ & $\mathrm{H}$ \\
\hline A & $S$ & W & $\mathrm{N}$ \\
\hline W & $P$ & $\mathrm{~S}$ & $\mathrm{H}$ \\
\hline W & $S$ & $\mathrm{~N}$ & $\mathrm{C}$ \\
\hline W & $S$ & $\mathrm{~N}$ & $\mathrm{H}$ \\
\hline W & $S$ & $\mathrm{~N}$ & E \\
\hline W & $S$ & $\mathrm{~N}$ & $\mathrm{~N}$ \\
\hline W & $P$ & $\mathrm{~W}$ & $\mathrm{~N}$ \\
\hline W & $\mathrm{L}$ & $\mathrm{N}$ & $\mathrm{H}$ \\
\hline W & $S$ & $\mathrm{C}$ & E \\
\hline W & $S$ & $\mathrm{~N}$ & $\mathrm{~N}$ \\
\hline A & $\mathrm{L}$ & $\mathrm{S}$ & $\mathrm{H}$ \\
\hline A & $S$ & $\mathrm{~N}$ & $\mathrm{~N}$ \\
\hline A & $S$ & $\mathrm{~S}$ & $\mathrm{H}$ \\
\hline $\mathrm{F}$ & $\mathrm{L}$ & W & $\mathrm{N}$ \\
\hline $\mathrm{U}$ & $\mathrm{L}$ & W & E \\
\hline $\mathrm{F}$ & $P$ & $\mathrm{C}$ & $\mathrm{N}$ \\
\hline $\mathrm{F}$ & $\mathrm{L}$ & $\mathrm{C}$ & $\mathrm{C}$ \\
\hline W & $S$ & $\mathrm{~W}$ & $\mathrm{~N}$ \\
\hline W & $\mathrm{L}$ & $\mathrm{S}$ & $\mathrm{C}$ \\
\hline A & $S$ & $\mathrm{~N}$ & $\mathrm{H}$ \\
\hline A & $\mathrm{P}$ & $\mathrm{W}$ & $\mathrm{N}$ \\
\hline $\mathrm{U}$ & $\mathrm{R}$ & $S$ & $\mathrm{H}$ \\
\hline W & $S$ & $\mathrm{~N}$ & $\mathrm{~N}$ \\
\hline W & $S$ & $\mathrm{~N}$ & $\mathrm{~N}$ \\
\hline W & $S$ & $\mathrm{C}$ & $\mathrm{C}$ \\
\hline $\mathrm{F}$ & $\mathrm{R}$ & $\mathrm{N}$ & $\mathrm{H}$ \\
\hline W & $S$ & $\mathrm{C}$ & $\mathrm{C}$ \\
\hline $\mathrm{F}$ & $\mathrm{R}$ & W & E \\
\hline W & $\mathrm{S}$ & $\mathrm{N}$ & $\mathrm{H}$ \\
\hline A & $\mathrm{L}$ & $S$ & $\mathrm{C}$ \\
\hline $\mathrm{F}$ & $\mathrm{P}$ & W & $\mathrm{N}$ \\
\hline $\mathrm{F}$ & $\mathrm{L}$ & $\mathrm{W}$ & $\mathrm{H}$ \\
\hline $\mathrm{U}$ & $S$ & $\mathrm{~W}$ & $\mathrm{~N}$ \\
\hline $\mathrm{U}$ & $P$ & $\mathrm{~S}$ & $\mathrm{~N}$ \\
\hline $\mathrm{F}$ & $\mathrm{R}$ & $\mathrm{N}$ & $\mathrm{N}$ \\
\hline $\mathrm{U}$ & $\mathrm{P}$ & $\mathrm{W}$ & $\mathrm{N}$ \\
\hline $\mathrm{F}$ & $S$ & $\mathrm{~N}$ & $\mathrm{~N}$ \\
\hline A & $\mathrm{L}$ & $\mathrm{N}$ & $\mathrm{E}$ \\
\hline $\mathrm{F}$ & $\mathrm{R}$ & $\mathrm{S}$ & $\mathrm{N}$ \\
\hline $\mathrm{F}$ & $\mathrm{R}$ & $\mathrm{N}$ & $\mathrm{N}$ \\
\hline $\mathrm{U}$ & $\mathrm{L}$ & $S$ & E \\
\hline $\mathrm{F}$ & $\mathrm{L}$ & $S$ & $\mathrm{H}$ \\
\hline W & $\mathrm{R}$ & $\mathrm{W}$ & $\mathrm{N}$ \\
\hline W & $\mathrm{L}$ & $\mathrm{C}$ & E \\
\hline $\mathrm{F}$ & $S$ & $\mathrm{~N}$ & $\mathrm{H}$ \\
\hline
\end{tabular}


Columba oenas

Columba palumbus

Coracias garrulus

Corvus corax

798 Corvus cornix

799 Corvus corone

800 Corvus frugilegus

801 Corvus monedula

802 Coturnix coturnix

803 Crex crex

804 Cuculus canorus

805 Cygnus olor

806 Delichon urbica

807 Dendrocopos leucotos

808 Dendrocopos major

809 Dendrocopos medius

810 Dendrocopos minor

811 Dendrocopos syriacus

812 Dryocopus martius

813 Egretta alba

814 Egretta garzetta

815 Emberiza citrinella

816 Emberiza hortulana

817 Emberiza schoeniclus

818 Erithacus rubecula

819 Falco cherrug

$820 \quad$ Falco peregrinus

821 Falco subbuteo

822 Falco tinnunculus

823 Falco vespertinus

824 Ficedula albicollis

825 Ficedula hypoleuca

826 Ficedula parva

827 Fringilla coelebs

$828 \quad$ Fulica atra

829 Galerida cristata

830 Gallinago gallinago

831 Gallinula chloropus

832 Garrulus glandarius

833 Glaucidium passerinum

Grus grus

836 Himantopus himantopus Hippolais icterina

839 Charadrius dubius

840 Charadrius hiaticula

841 Charadrius morinellus

842 Chlidonias hybridus

843 Chlidonias niger

844 Ixobrychus minutus

845 Jynx torquilla

846 Lanius collurio

847 Lanius excubitor

848 Lanius minor

849 Lanius senator

850 Larus cachinnans

S

$S$

W

W

W

$\mathrm{S}$

W

W

S

C

W

$S$

$\mathrm{N}$

W

C

W

W

W

C

$\mathrm{N}$

S

$\mathrm{N}$

S

S

W

W

$\mathrm{N}$

W

C

W

W

W

C

C

$\mathrm{N}$

$\mathrm{N}$

W

W

S

$\mathrm{N}$

W

W

$\mathrm{N}$

$\mathrm{N}$

$\mathrm{N}$

S

$\mathrm{N}$

W

W

$\mathrm{N}$

$\mathrm{N}$

S

C

S

W

N

W

S

S

S
H

$\mathrm{N}$

$\mathrm{N}$

$\mathrm{H}$

$\mathrm{N}$

C

E

$\mathrm{N}$

$\mathrm{N}$

$\mathrm{N}$

$\mathrm{H}$

$\mathrm{H}$

$\mathrm{H}$

$\mathrm{N}$

$\mathrm{N}$

N

$\mathrm{H}$

$\mathrm{N}$

E

$\mathrm{N}$

$\mathrm{H}$

$\mathrm{N}$

$\mathrm{H}$

$\mathrm{H}$

$\mathrm{N}$

$\mathrm{N}$

C

C

$\mathrm{H}$

$\mathrm{N}$

C

$\mathrm{N}$

$\mathrm{N}$

$\mathrm{H}$

$\mathrm{N}$

N

E

$\mathrm{H}$

$\mathrm{N}$

$\mathrm{N}$

$\mathrm{H}$

C

C

$\mathrm{N}$

$\mathrm{N}$

E

$\mathrm{N}$

$\mathrm{N}$

C

$\mathrm{N}$

C

H

E

E

$\mathrm{H}$

H 
856 Locustella luscinioides

\section{Locustella naevia}

A

W

Loxia curvirostra

859 Lullula arborea

860 Luscinia luscinia

861 Luscinia megarhynchos

862 Luscinia svecica cyanecula

863 Luscinia svecica svecica

864 Mergus merganser

865 Merops apiaster

866 Miliaria calandra

867 Milvus migrans

868 Milvus milvus

869 Motacilla alba

$870 \quad$ Motacilla cinerea

871 Motacilla flava

872 Muscicapa striata

873 Netta rufina

$874 \quad$ Nucifraga caryocatactes

875 Numenius arquata

876 Nycticorax nycticorax

877 Oenanthe oenanthe

878 Oriolus oriolus

879 Otis tarda

880 Otus scops

881 Pandion haliaetus

882 Panurus biarmicus

883 Parusater

884 Parus caeruleus

885 Parus cristatus

886 Parus major

887 Parus montanus

888 Parus palustris

889 Passer domesticus

890 Passer montanus

$891 \quad$ Perdix perdix

892 Pernis apivorus

893 Phalacrocorax carbo

894 Phasianus colchicus

895 Phoenicurus ochruros

896 Phoenicurus phoenicurus

897 Phylloscopus collybita

898 Phylloscopus sibilatrix

899 Phylloscopus trochiloides

900 Phylloscopus trochilus

901 Pica pica

902 Picoides tridactylus

903 Picus canus

904 Picus viridis

905 Platalea leucorodia

906 Podiceps cristatus

907 Podiceps grisegena

908 Podiceps nigricollis

909 Porzana parva

$910 \quad$ Porzana porzana 
911 Prunella collaris

912 Prunella modularis

$\begin{array}{llll}\text { A } & \text { S } & \text { S } & \text { H }\end{array}$

913 Pyrrhula pyrrhula

914 Rallus aquaticus

915 Recurvirostra avosetta

916 Regulus ignicapillus

917 Regulus regulus

918 Remiz pendulinus

919 Riparia riparia

920 Saxicola rubetra

921 Saxicola torquata

922 Scolopax rusticola

923 Serinus serinus

924 Sitta europaea

925 Sterna hirundo

926 Streptopelia decaocto

927 Streptopelia turtur

928 Strix aluco

929 Strix uralensis

930 Sturnus vulgaris

931 Sylvia atricapilla

932 Sylvia borin

933 Sylvia communis

934 Sylvia curruca

935 Sylvia nisoria

936 Tadorna tadorna

937 Tachybaptus ruficollis

F

W

$\mathrm{N}$

$\mathrm{N} \quad \mathrm{N}$

W

W

$S$

$\mathrm{H}$

$\mathrm{C}$

$\mathrm{N}$

F

W

A

A

A

F

$\mathrm{U}$

F

W

$\mathrm{U}$

A

F

F

F

F

F

A

U

A

$S$

$\mathrm{S}$

$\mathrm{N}$

S

W

$\mathrm{N}$

S

$\mathrm{N}$

S

W

$\mathrm{N}$

S

$\mathrm{S}$

W

N

W

W

W

W

$\mathrm{N}$

C

W

S

N

N

$\mathrm{N}$

$\mathrm{N}$

W

N

W

W

$\mathrm{N}$

N

W

939 Tetrao urogallus

Tringa ochropus

942 Troglodytes troglodytes

944 Turdus iliacus

945 Turdus philomelos

946 Turdus pilaris

947 Turdus torquatus

948 Turdus viscivorus 


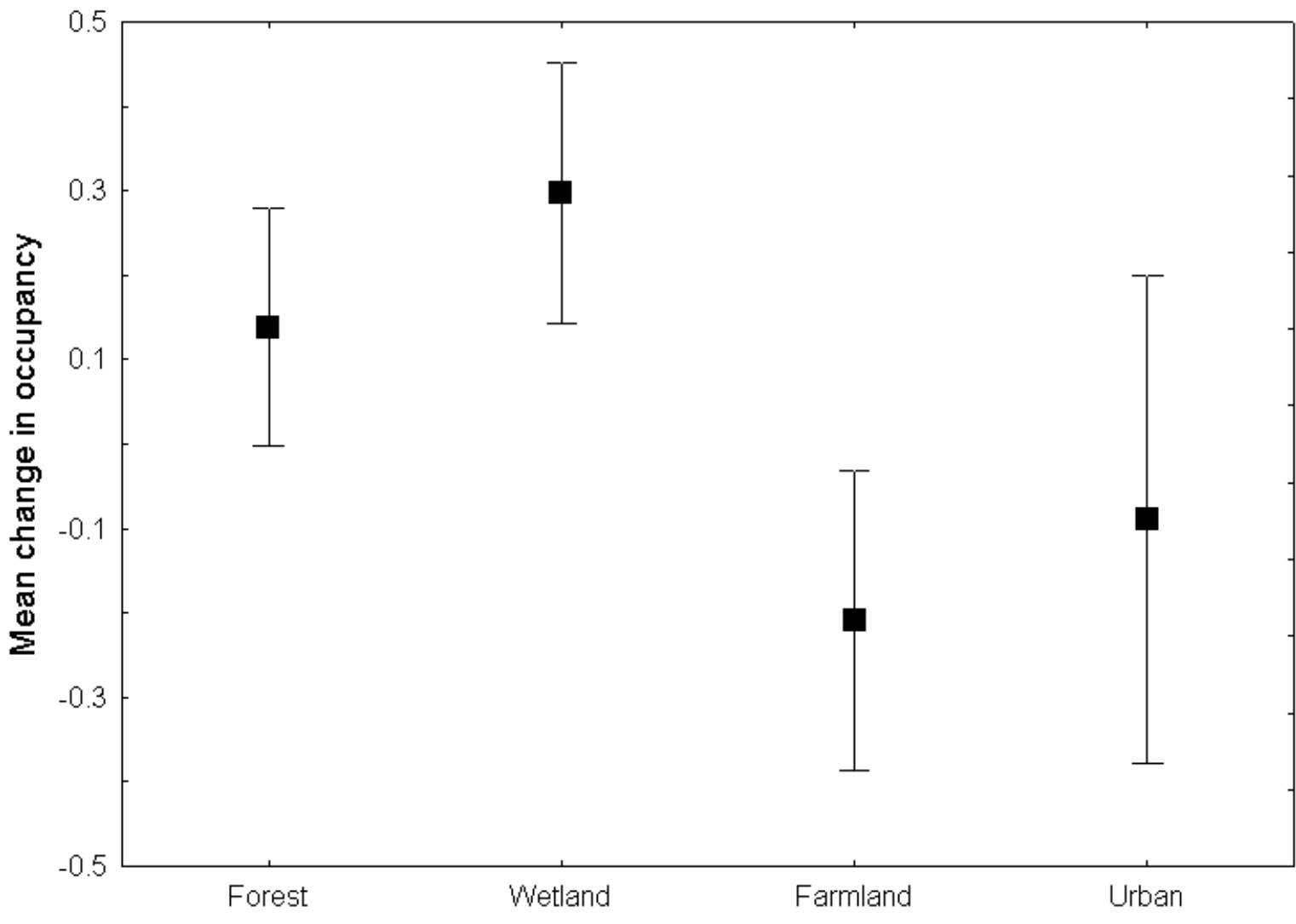

953

Habitat requirements 